\title{
AN INVESTIGATION OF PROBLEMS EXPERIENCED THROUGH ONLINE EDUCATION AND MEASURING DIGITAL LITERACY: AN EXPLORATORY STUDY OF TURKISH MASTERS' DEGREE AND PHD STUDENTS
}

\author{
Lokman Altun ${ }^{\mathrm{i}}$ \\ Sivas University of Science and Technology, \\ Turkey
}

\begin{abstract}
:
Coronavirus has changed the habits of all over the world deeply. This transformation has profoundly affected the way of the education system. Closing schools and universities carried education to online platforms. My university has also been using a new online education platform. Naturally, my students have been facing some problems during my lessons. I targeted to explore what kinds of problems have been experienced. My second aim of this exploratory research is to measure my students' digital literacy levels. The findings of my research showed that the learners were mostly facing problems such as internet connection, losing concentration, and social interaction. Furthermore, their digital literacy sub-scales were found as very good and good, but they have a problem with one side of digital literacy.
\end{abstract}

Keywords: digital, literacy, evaluation, online, education, problems

\section{Introduction}

Using technology has been unusual and indispensable part of all fields of our lives including education. Integrating technology into education is a new trend for both teachers and administrators as everything is becoming digital as well as for students. While technology is an indispensable part of our lives, knowing how to use it more effectively for teachers and students is another crucial skill. At this point, the term "digital literacy" has gained much more importance. Digital literacy is illustrated as a survival skill that includes skills and strategies being used by the students in a digital setting (Eshet-Alkalai, 2004). The importance of digital literacy is understood very well especially by facing to Covid-19. Even though the world keeps technology in their' hands, they encountered big obstacles while using technology in education. Especially in Turkey, it is seen that our teachers and students are having difficulties in using

i Correspondence: email laltun@sivas.edu.tr 
technology. In fact, students and teachers have to admit this technological transformation and realize that digital literacy is an important skill in the digital era (Saleem\& Batcha, 2014). Significantly for us language teachers and learners, being digital literate is much more necessary because teaching or learning language is one of the most common fields using technology. Our classes are being designed based on technological tools. As our target groups are born with technology, they are eager to utilize technology much more in their classes, too. So, the language learners ought to improve their digital literacy a lot to be able to take part in the digital environment in a new language (Hafner, Chik \& Jones, 2015).

For months, all schools and universities in Turkey have been using online education because of coronavirus. At this point, as I clarified before, the digital literacy skills of the learners and teachers have gained importance to make online education more beneficial. As Bruce and Hogan (2000) stated that the learners who are in higher education need to have skills such as using technology to explore, examine, argue, and get across information. I am also teaching English to my doctorate and master's degree students through online platforms. During the teaching process, I realized that my students are having difficulties in using technology such as sending homework, making a presentation, exploring an idea, discussing any notion, etc. Accordingly, I just wanted to find out what kind of problems they have experienced during online education. I suppose that these kinds of difficulties are causing because of not having enough digital literacy skills and I also aspired to learn my learners' digital literacy levels.

Very importantly, without being literate digitally, keeping online education up will be aimless for me and the learners. As Marzilli, Delello, Marmion, McWhorter, Roberts, and Marzilli (2014) clarify that being deficient in digital literacy knowledge for the learners, being short of skills and competencies to apply technology in classroom teaching are principal troubles in learning. This exploratory study tries to answer the following research questions:

1) What are my students' experienced problems during online education?

2) To what extent are the participants in my class digitally competent?

\section{Literature Review}

Digital literacy has started being researched lately and its' importance became much more with Covid-19 because all countries have begun to integrate technology into their education systems as much as possible. In fact, the definition of digital literacy was introduced firstly years ago by Gilster (1997) as the skill to be able to get information from a different context and to use digital technologies precisely and neatly. Qin and D'ignazio (2010) clarify the difference between information literacy and digital literacy. He pointed out that digital literacy is a skill, consciousness, reaction, and utilization of digital technology while information technology is mainly concerned about discovering, getting, analyzing, using information for lifelong learning and the latter is an individual ability. Of course, digital literacy is just not effective for digital learning. As it is mentioned 
before, it has another dimension supporting academic success that instructively literate by being qualified for living, getting, and working in a digital community (Beetham, 2010).

Digital literacy is not including just one aspect. It combines different skills. Since digital skills are seen as an obligatory process, attempts to clarify these skills and to report them have emerged for the last twenty years (Riel, Christian \& Hinson, 2012). Mishra (2019) explains other parts by stating that digital literacy is multiple approaches to evaluate information necessities and reach information digitally. Walker and White (2015) expand these components by saying that determining, comprehending, and fixing the digital needs of the participants are fundamental aspects. When these elements of digital literacy are checked, it mainly attributes to be literate digitally in academic and school environments. James Gee (2007) argues digital literacy aspects from a different perspective. He principally calls attention to the social aspect of digital literacy. He illustrates his notions that new digital literacy has a cultural, situated role because reading or writing digitally is not just an achievement mentally but also a cultural and communal activity.

In this field, there are published studies studying different aspects of digital literacy. Mishra (2019) wanted to explore and research the perception of faculty on digital literacy. His main target was to find out their abilities in utilizing digital skills at school. Another objective was to also identify the members' needs in terms of digital literacy. Interviews and questionnaires were applied to 102 participants. He found out that most participants were aware of the significance of digital literacy and they found it as a crucial skill in the digital era. The participant's answers also showed that they thought of themselves as good digital users, but they also gave advice to the school to implement digital innovations to the curriculum much more.

Kikon (2019) measured the Digital Literacy levels and skills of two different school students. She wanted to show what their digital skills basically. She used a questionnaire that aims to find out the learners' digital skills. 52 respondents filled the questionnaire. With the help of SPSS and MS excel, she found that \%37 of the learners were good while $\% 8$ of them were poor in terms of digital literacy. The best skill was chosen as typing online and using web-search websites.

Tour, Gindidis, and Newton (2019) explored the learners' digital literacies by using the digital storytelling method. As it is an exploratory study, they used reflective journals, students' works, and interviews. The participants were 7th-grade students. This digital storytelling method which activates authentic communication through artificial contexts helped the teacher to improve students' comprehension as well as technical skills. It is also a new approach that will lead the learners to be more creative in learning a language without feeling under pressure and practice their digital skills. 


\section{Methodology}

This is exploratory research. So, I wanted to explore a situation that happened in class and get an answer to my problem in the class. I was observing that my students were challenged by some technical problems during my online lessons such as not being able to send homework online, correcting their mistakes based on online feedback, making presentations, reading, and understanding, etc. That is why I sought to explore this problem. While the topic of the coursebook was technology, I assigned them to write a paragraph including at least 150 words about the problems they experienced during online education so as to understand what kind of problems faced by my students during online education. I had 15 students with masters' degree and Ph.D. students from age 24 to 41 in my classes and all of them responded to my homework and sent their works to me via email. I checked problems and noted them. After taking notes, I ordered them one by one and found out the most experienced problems.

After specifying their problems, I supposed that their problems might have been caused because of inadequate digital literacy skills. I decided to measure their digital literacy skills by using a questionnaire developed by Misirli and Akbulut (2013). This questionnaire was created to explore the learners' digital literacy skills. This scale consists of 21 items with 4 different sub-scales (technical proficiency, creativity, digital citizenship, and participation, innovativeness). Students answered to each by using Likert-Scale with 5 points ranging from strongly agree (5) to agree (4) to neutral (3) to disagree (2) to strongly disagree (1). I formed this scale by using Google Form then I shared the link of the questionnaire with my students to fill it (see Appendix A). All students completed the questionnaire. Based on my students' grades, I calculated the average scores of each sub-scale by using MS Excel. I evaluated the average scores of each sub-scale whether that sub-scale is sufficiently digital literate or not based on the table below proposed by the researchers.

Table 1: Level of Competence Based on Average Scores

\begin{tabular}{|l|c|}
\hline Range & Level of Competence \\
\hline $1,00-1,80$ & Very Poor \\
\hline $1,81-2,60$ & Poor \\
\hline $2,61-3,40$ & Neutral \\
\hline $3,41-4,20$ & Good \\
\hline $4,21-5,00$ & Very Good \\
\hline
\end{tabular}

\section{Findings}

After evaluating responses, it was clearly seen that my students had mostly encountered connection problems. That is the most popular obstacle written by students in their homework. 
"Also, I mostly experienced unidentified connection problems and couldn't solve these problems. Therefore, my lectures or lessons were interrupted."

"And of course, the most important thing is high quality internet connection. As the internet is not stable, synchronization problems occurred during education."

"Additionally, connection problems made it very difficult for me to attend classes."

"In addition, since everybody works on the internet in such a period, the speed of the internet decreases. For example, when I was making a presentation last week, the internet was suddenly cut off."

Another biggest problem was considered as losing concentration. As the digital world may disturb students easily, students are probably affected by these situations.

"For example, while connecting to the online lesson from home, I was exposed to other situations at that time. For example, my sister called me, or my nephew entered to room and shouted suddenly). As a student, my concentration may be distracted over time."

"One of the most obvious difficulties I encountered as a student in online education was the problem of focusing and not being able to fully address the issue."

"Finally, while I attended at home, my son Bünyamin was constantly involved in the lessons. :) Now, all the academic staff at the school have known him. Aside from his humor, that's why I can't concentrate on many lessons."

Thirdly, lacking social interaction was highlighted by students a lot. Students could not find a chance to socialize in the digital environment.

"On the other hand, I realized that I could not express myself fully in online education.

Because gestures and mimics are important parts to understand people. For this reason, I have been misunderstood by many of my academician students."

"Since the teacher cannot provide direct eye contact with the students, the efficiency of the lesson also decreases."

"Furthermore, I am forced to provide feedback such as tests, exams, etc. For this reason, healthy interaction couldn't be ensured between me and lecturers."

The next common obstacle was expressed by my learners as financial difficulties. My learners pointed out that they had not always find enough financial power to provide technological tools. 
"Finally, education by using the internet is costly since it has expensive equipment which are computer, infrastructure of internet, mobile phone, television. So, my financial situation cannot enough for online education."

"Secondly, Sometimes I couldn't find any phone or computer. So, I couldn't join to online lessons."

During this online education process, online platforms have been used a lot but seemingly, my students also did not like our online education platform so much.

"One more thing is Big Blue Button. BBB is the system actually where we joined the online lessons. Sometimes I can't use my microphone."

"Online education platform infrastructure was insufficient."

"Furthermore, system-related errors prevented the course from progressing properly. For example, the listening part cannot be done in English lessons due to the system error and the teacher had to find other solutions for this."

Other problems were specified as teachers with inadequate knowledge on technology use, being inexperienced in terms of using technology from the viewpoint of the learners, problems of finding suitable places for online education at job, lacking real lecture atmosphere and health problems.

"The biggest disadvantage of the online education for me is the absence of a suitable environment in the office."

"I couldn't know how to utilize computer completely because I hadn't got computer."

"On the other hand, we had to face many problems because we hadn't so many experiences before."

"The inadequacy of the teaching staff can be added to many disadvantages."

"The second biggest problem is the lack of a real lecture atmosphere."

"I had some health problems because I used computers for a long time." 
AN INVESTIGATION OF PROBLEMS EXPERIENCED THROUGH ONLINE EDUCATION AND MEASURING DIGITAL LITERACY: AN EXPLORATORY STUDY OF TURKISH MASTERS' DEGREE AND PHD STUDENTS

\begin{tabular}{|l|c|}
\hline \multicolumn{2}{c}{ Table 2: Average Points of Sub-scales of Digital Literacy } \\
\hline Average Points & $\overline{\mathbf{X}}$ \\
\hline Technical proficiency & 4,21 \\
\hline Creativity & 3,87 \\
\hline Digital citizenship and participation & 4,03 \\
\hline Innovativeness & 4,34 \\
\hline
\end{tabular}

Total: 4,11

After identifying my students' problems, I checked their digital literacy levels, too. According to my students' responses, Table 3 was formed. Table 3 showed me that my students' innovativeness was found out as 4,34. Based on Table 1, this score explained to me that my students' innovativeness was "very good" in terms of digital literacy subscale. In the same way, technical proficiency was indicated as "very good". Digital citizenship and participation were another sub-scale of digital literacy and calculated as 4,03 and it means that my students were "good" in terms of digital citizenship and participation. However, creativity had the least average point of 3,87 . This showed me as their teachers that my students had struggled with the creativity side of digital literacy. Even though 3,87 was described as "good" based on Table 1, there was a huge difference between creativity and other sub-scales.

\section{Conclusion}

My main objective was to see my students' problems with online education and to recognize their basic digital literacy skills. First of all, I collected their writings about the problems they faced then I started taking notes and finding the problems. I realized that nearly most of my students came across the internet connection problem. In fact, this problem needs to be most thought about. Internet connection is the indispensable component of online education. Without it, online education cannot be thought of. Rahmah (2015) affirms that the internet is a vital need at this time, not a filling tool. Apart from the internet connection, naturally, my students could not focus on my lessons for a long time. This is another remarkable result for me and the other teachers. Our students are not machines but just humans and they can lose their attractions easily even in faceto-face education. While there is no school environment, concentration problems are getting more and more typical. This concentration problem is probably happening because there is no eye contact. In my lessons, I directly looked at a student who is looking outside of a class or dreaming something. Unfortunately, we as educators have no chance to warn or look at our students' eyes directly during online education. This leads me to the third problem: social interaction. The classroom is a platform for students that gives opportunities to talk, have fun, cheer, etc. In short, it provides an funny and social environment our students. They interact with us, their friends but they are not finding this environment in an online platform because everyone is individual there. This is normally seen as the biggest obstacle of my learners. Teachers who are not so good at the digital world is also expressed by my learners. If the learners feel that their teachers do 
not know how to use technology effectively or integrate technology into their lessons, this creates chaos in class during online education because online education means qualified online teachers. Everything depends on the teachers and they are controlling everything. They have to know every detail of systems and integration of technology to education. Otherwise, as my students clarified, students will not take them seriously. The study of Al Khateeb (2017) also has the same result as my study. The researcher found out that the teachers are not digitally skillful. They are not meeting the standards and levels of digital teachers of the 21st century. Another side of this problem is that my students are not also digitally competent. This is probably because of their ages. They are not digital natives which is a term claimed by Prensky (2001). They are not so familiar with the digital world and they are trying to get used to this situation. As a result, they are suffering because of online education. Zilka (2017) explains the source of this problem by stating that not having enough knowledge about the capacity of tools, platforms or websites is the result of incompetent technology knowledge because when they feel their deficiencies of digital literacy, they will experience concern and fears. Financial difficulties are not so common among my learners as they are master's degree and Ph.D. students, but this is the problem of all students all over the world. Technological education demands financial power. You need to reach the internet, to get a computer, phone, or tablet, to find a place, etc. All of these are directing me to financial difficulties. Even my students who had not difficulty in this issue a lot encountered this handicap sometimes. This result is in concordance with Zilka (2017, p. 95). Zilka also found out that the children who reach computers developed their ICT awareness and digital literacy knowledge considerably.

Another conclusion of this exploratory study is that my students have very good innovativeness, technical proficiency in digital sub-scales. As my students are engineering students even though they are not digital natives, they have to adapt to new technological innovations. These are their major components for their jobs. So, their innovative side of digital literacy is very high. Technical proficiency items were about generally using social sites. As the social world is highly engaged in our lives, my students have a natural awareness of using social web sites. This result is correlated with the study of Kikon (2019, p.287) and Caverly, Payne, Castillo, Sarker, Threadgill, and West (2019). Her study also found out that the learners were very good in terms of web search skills. Digital citizenship is found as good on the contrary. This apparently explains the problems of my students experienced in my lessons. This item was about participating in online discussions or declaring opinions online. My study showed that they were not as good as innovativeness and technical proficiency. Surprisingly, creativity has the least average score. Seemingly, my learners have really big difficulties to create something by using digital technologies. Even though they were engineering students, the side of creativity apparently did not develop a lot. This also clarifies my point of the study. During online education, they have to be creative by using technology. Transforming their knowledge into practice is the key point. As they do not have enough knowledge about creating something, they are facing problems during online education. 


\section{Reflection}

By considering the results of my study, I as a teacher have much more awareness in terms of efficiency of social interaction and concentration. The teachers may not have deep understanding the importance of these sides when they are at class environment, but online teaching environment is lacking these sides. We should include activities that provide interaction among them. I also realize that the educators should keep the learners active during the lesson hours. It can be also aided by using interaction, directing questions, playing games, etc. Teachers also should be well equipped with technological tool that they use actively during online education if they want to see respect from their students. These sides related to the educators, but the most important part is about institutions and countries. They have to ensure fast and quality internet connection in all parts of country. The internet that is crucial component of online education should be reached by the learners and educators wherever they are. Countries must also put financial assistance on the agenda immediately to pursue online education throughout the years. Other results directed the learners to focus on the side of creativity during online education. We must design and present activities that provide the learners to form unique works. Creativity should be emphasized with these kinds of activities.

\section{Conflict of Interest Statement}

The author declares no conflicts of interests.

\section{About the Author}

Lecturer Lokman Altun is working at School of Foreign Languages, Sivas University of Science and Technology University. After he took Master's degree in ELT, he is doctorating in ELT now. He is mainly interested in integrating technology to language education and second language acquisition.

\section{References}

Al Khateeb, A. A. M. (2017). Measuring Digital Competence and ICT Literacy: An Exploratory Study of In-Service English Language Teachers in the Context of Saudi Arabia. International Education Studies, 10(12), 38-51.

Beetham, H. (2010). Review and scoping study for a cross-JISC learning and digital literacies programme, JISC.

Bruce, B., \& Hogan, M. (2000). The disappearance of technology: Toward an ecological model of literacy. Handbook of literacy and technology: Transformations in a post-typographic world (pp. 269-281). Mahwah, NJ: Lawrence Erlbaum Associates.

Caverly, D. C., Payne, E. M., Castillo, A. M., Sarker, A., Threadgill, E., \& West, D. (2019). Identifying Digital Literacies to Build Academic Literacies. Journal of College Reading and Learning, 49(3), 170-205. 
Eshet, Y. (2004). Digital literacy: A conceptual framework for survival skills in the digital era. Journal of educational multimedia and hypermedia, 13(1), 93-106.

Gee, J. P. (2007). Pleasure, learning, video games, and life: The projective stance. A new literacies sampler, 29, 95.

Gilster, P. (1997). Digital literacy. New York: John Wiley \& Sons.

Hafner, C. A., Chik, A., \& Jones, R. (2015). Digital literacies and language learning. Language Learning \& Technology 19 (3): 1-7

Kikon, Pichano. "International Conference on Librarianship Development Through Internet of Things and Customer Service." Gujarat Power Engineering and Research Institute, International Conference Proceeding, 2019, pp. 284-292.

Marzilli, C., Delello, J., Marmion, S., McWhorter, R., Roberts, P., \& Marzilli, T. (2014). Faculty attitudes towards integrating technology and innovation. International Journal on Integrating Technology in Education, 3(1), 1-20.

Mishra, C. (2019). Faculty perceptions of digital information literacy (DIL) at an Indian university: an exploratory study. New Review of Academic Librarianship, 25(1), 7694.

Misirli, Z. A., \& Akbulut, Y. (2013). Development of a Scale to Explore Technology Literacy Skills of Turkish 8th Graders. Contemporary Educational Technology, 4(4), 249-262.

Prensky, M. (2001). Digital natives, digital immigrants. On the Horizon, 9(5), 1-6.

Qin, J., \& D'ignazio, J. (2010). The central role of metadata in a science data literacy course. Journal of Library Metadata, 10(2-3), 188-204.

Rahmah, A. (2015). Digital literacy learning system for Indonesian citizen. Procedia Computer Science, 72, 94-101.

Riel, J., Christian, S., \& Hinson, B. (2012). Charting digital literacy: A framework for information technology and digital skills education in the community college. Available at SSRN 2781161.

SZ, S. T., Saleem, A., \& Batcha, M. S. (2014). Digital literacy awareness among arts and science college students in Tiruvallur district: A study. International Journal of Managerial Studies and Research, 2(4), 61-67.

Tour, E., Gindidis, M., \& Newton, A. (2019). Learning digital literacies through experiential digital storytelling in an EAL context: an exploratory study. Innovation in Language Learning and Teaching, 1-16.

Walker, A., \& White, G. (2015). Technology-enhanced Language Learning: Connecting Theory and Practice. Oxford: Oxford University Press.

Zilka, G. C. (2017). Awareness of ICT capabilities, digital literacy, and use of reflective processes in children who received their first home computer. International Journal of Technology Enhanced Learning, 9(1), 80-98. 

will be applied to their work. Under the terms of this license, no permission is required from the author(s) or publisher for members of the community to copy, distribute, transmit or adapt the article content, providing a proper, prominent and unambiguous attribution to the authors in a manner that makes clear that the materials are being reused under permission of a Creative Commons License. Views, opinions, and conclusions expressed in this research article are views, opinions, and conclusions of the author(s). Open Access Publishing Group and European Journal of Foreign Language Teaching shall not be responsible or answerable for any loss, damage, or liability caused in relation to/arising out of conflicts of interest, copyright violations, and inappropriate or inaccurate use of any kind content related or integrated into the research work. All the published works are meeting the Open Access Publishing requirements and can be freely accessed, shared, modified, distributed, and used in educational, commercial, and non-commercial purposes under a Creative Commons Attribution 4.0 International License (CC BY 4.0). 